Dit artikel is met toestemming van de redactie overgenomen uit TvZ verpleegkunde in praktijk en wetenschap, 2019, nr. 1, www.tvzdirect.nl

PANEL V\&V

\title{
Patiëntportalen: \\ meer overzicht zorg
}

Verpleegkundigen en verzorgenden vinden het belangrijk dat patiënten via een portaal hun eigen zorggegevens kunnen inzien. Hoewel er ook zorgen zijn rondom het gebruik, verwachten verpleegkundigen en verzorgenden dat een portaal patiënten meer inzicht in het behandel- of zorgplan en een beter overzicht van hun zorg geeft. Dit blijkt uit een onderzoek onder de deelnemers van het Nivel Panel Verpleging \& verzorging in het kader van de eHealth-monitor 2018.

auteurs

ILSE SWINKELS

senior onderzoeker bij het Nivel

KIM DE GROOT

onderzoeker bij het Nivel en wijkverpleegkundige bij

Thebe Wijkverpleging

ANNE BRABERS

onderzoeker bij het Nivel

MYRAH WOUTERS

senior adviseur e-health bij

Nictiz

ANKE DE VEER

senior onderzoeker bij het Nivel
$\mathrm{S}$ TEEDS MEER VERPLEEGKUNDIGEN en verzorgenden leggen zorggegevens elektronisch vast. Hierdoor ontstaat ook de mogelijkheid online inzage te bieden aan patiënten. De gedachte is dat (online) inzage patiënten helpt om zelf de regie te hebben of te krijgen over hun gezondheid.

\section{Patiëntportalen gewenst}

Bijna negen van de tien verpleegkundigen en verzorgenden in de ouderenzorg vinden het gewenst dat patiënten inzage hebben in hun gegevens via een patiëntportaal. Ook in de huisartsenzorg en ziekenhuiszorg wordt online inzage breed gedragen. In deze sectoren vinden acht van de tien verpleegkundigen een patientportaal gewenst. Slechts een fractie van de verpleegkundigen en verzorgenden vindt het ongewenst (2-5 procent). Een iets grotere groep heeft hier geen mening over (10-14 procent).

Verpleegkundigen en verzorgenden verwachten of ervaren vooral dat een patiëntportaal patiënten (en/of mantelzorgers) meer inzicht geeft in het behandelplan of zorg(leef)plan. Patiënten zullen zich meer betrokken voelen bij de zorg, zo vinden verpleegkundigen en verzorgenden. Een ander effect dat verwacht of ervaren wordt is dat patiënten de mogelijkheid hebben om het zorgdossier te controleren. Krijgt de patiënt door online inzage ook meer regie? Volgens zes van de tien verpleegkundigen en verzorgenden in de ouderenzorg en ziekenhuiszorg wel. In de huisartsenzorg is dat met ruim acht van de tien beduidend hoger.

\section{Gegevens juist vastleggen}

In de ouderenzorg en ziekenhuiszorg verwacht of ervaart circa de helft van de verpleegkundigen en verzorgenden dat een patiëntportaal leidt tot een grotere druk om gegevens op de juiste manier vast te leggen. In de huisartsenzorg geeft bijna twee derde dit aan. In alle drie de sectoren verwacht of ervaart iets meer dan een derde meer tijd kwijt te zijn aan administratie.

\section{Aanbod verschilt per sector}

In de ouderenzorg werkte het afgelopen jaar iets meer dan de helft van de verpleegkundigen en verzorgenden met een patiëntportaal. Dit is hoger dan in 2017: toen lag dit op 42 procent. In de ziekenhuis- en huisartsenzorg geeft respectievelijk 42 en 32 procent van de verpleegkun- 


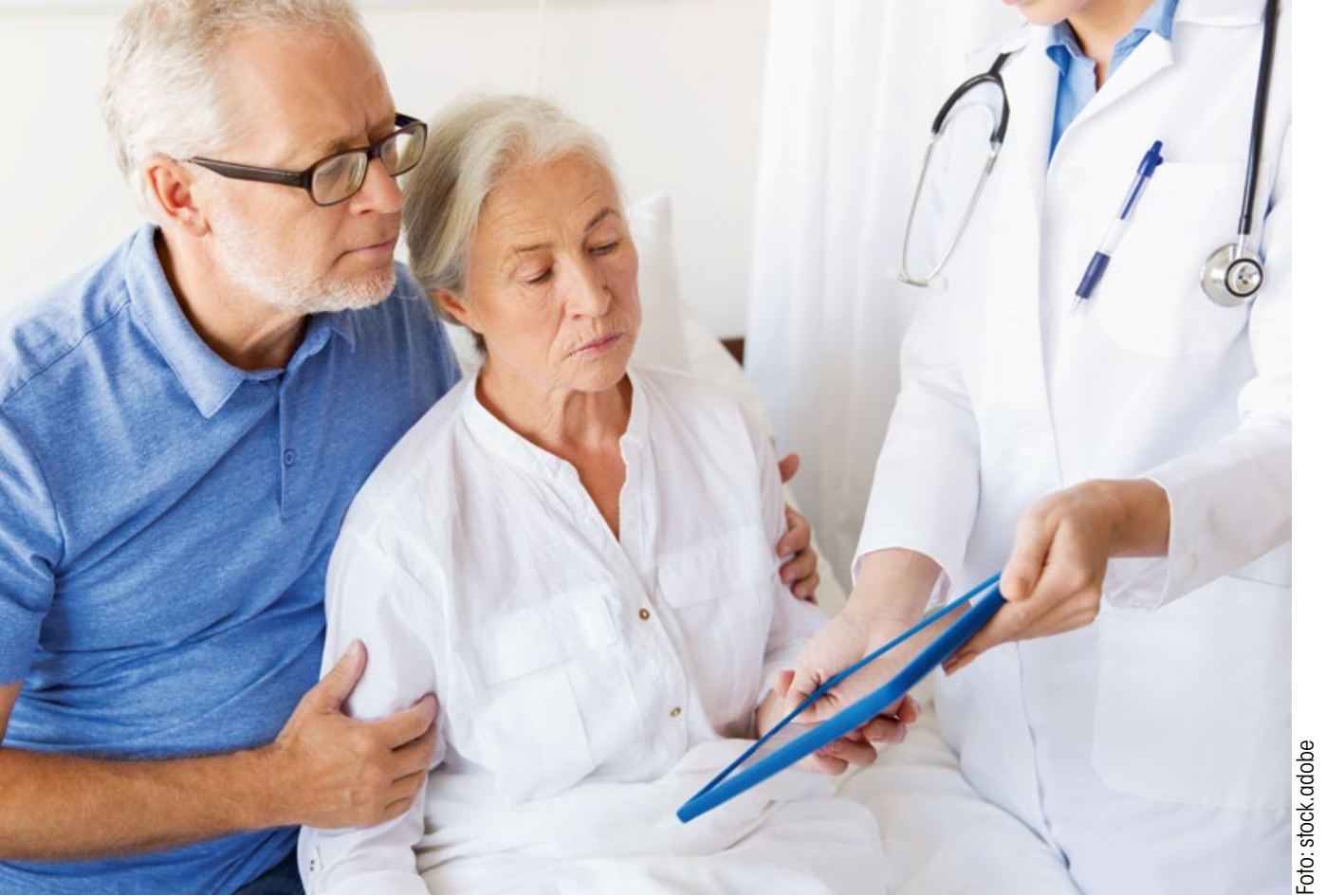

digen en verzorgenden aan het afgelopen jaar met een patiëntportaal te hebben gewerkt. Dit was in 2017 respectievelijk 38 en 31 procent. Ongeveer een vijfde van de verpleegkundigen en verzorgenden zegt dat er plannen zijn om binnen een jaar een patiëntportaal aan te bieden. Volgens verpleegkundigen en verzorgenden in de ouderenzorg geven de patiëntportalen vooral een overzicht van behandeldoelen en -afspraken over de zorg (zie figuur 1), gevolgd door inzicht in uitslagen van metingen (zoals bloeddruk). In de ziekenhuiszorg hebben patiënten vooral toegang tot uitslagen van onderzoek en overzichten van behandeldoelen en -afspraken. In de huisartsenzorg hebben patiënten ook het vaakst toegang tot uitslagen van onderzoek en de voorgeschreven medicijnen.

\section{Voorbereid op de toekomst}

Door wetgeving dient vanaf 2020 iedere patiënt die daar om vraagt elektronische inzage in het dossier krijgen. Daar lijkt bij de verpleegkundigen en verzorgenden voldoende draagvlak voor, aangezien meer dan 80 procent van hen online inzage wenselijk vindt. Wellicht worden verpleegkundigen en verzorgenden hiertoe gedreven doordat zij in het algemeen vaak en intensief contact hebben met de patiënt. Vorig jaar zagen we bijvoorbeeld ook al dat ze zich sterk verantwoordelijk voelen om patiënten te ondersteunen bij de keuze voor en het gebruik van e-health-toepassingen. ${ }^{1}$

Toch zijn er ook zorgen bij de verpleegkundigen en verzorgenden. Het is belangrijk deze te adresseren in implementatietrajecten.
Dit artikel is gebaseerd op een vragenlijst ingevuld door 660 verpleegkundigen, verzorgenden en praktijkondersteuners van het Nivel Panel Verpleging \& Verzorging (respons 46 procent) in het kader van onderzoek voor de eHealth-monitor. Voor de leesbaarheid spreken we in het artikel over verpleegkundigen en verzorgenden. Zie voor meer informatie de publicatie E-health in verschillende snelheden. ${ }^{2}$ Het onderzoek werd gefinancierd door het ministerie van Volksgezondheid, Welzijn en Sport en uitgevoerd door het Nivel en Nictiz. Voor meer informatie over het panel: www. nivel.nl/panelvenv.

\section{REFERENTIES}

1. Wouters M, Swinkels I, Sinnige

J, e.a. Kies bewust voor eHealth. eHealth-monitor 2017. Den Haag/ Utrecht: Nictiz/Nivel; 2017.

2. Wouters M, Swinkels I, Lettow van B, e.a. E-health in verschillende snelheden. eHealth-monitor 2018. Den Haag/Utrecht: Nictiz/Nivel; 2018.

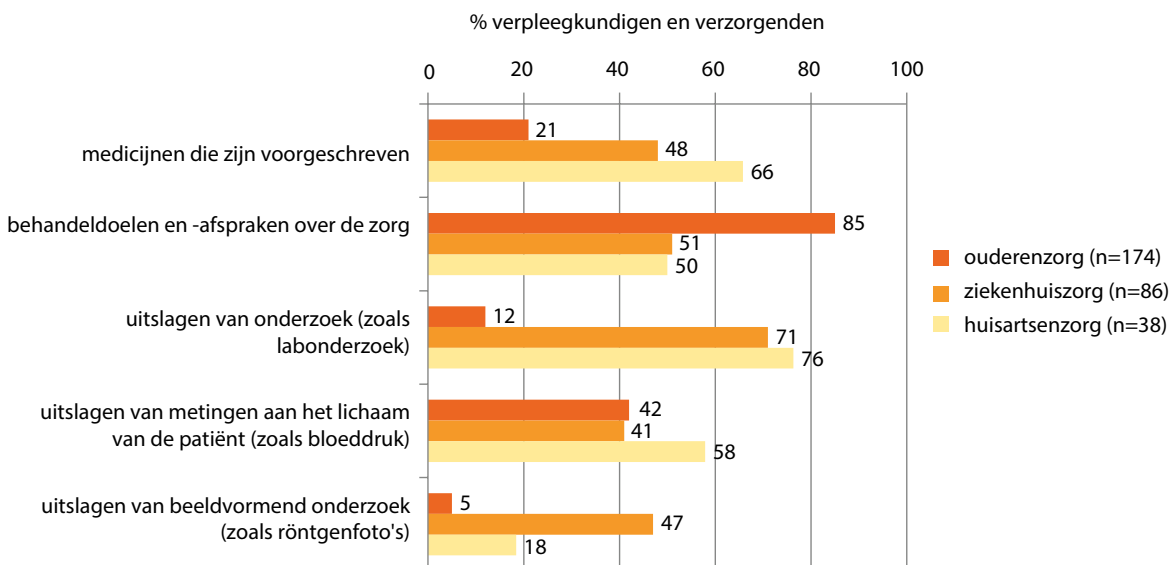

